\title{
PAUL THE JEW, POWER OF EVIL AND ROME ${ }^{1}$
}

\author{
Jeremy Punt \\ Stellenbosch University
}

\begin{abstract}
Continuing to read the Pauline letters as 'Christian' theological treatises side-lines their author's Jewishness and life in the Roman Empire. Paul's Jewishness within Empire is important for understanding the letters' take on power and also the powers. His Jewish identity and life in Empire informed which powers Paul addressed, how he understood their nature, and how he related to them. This contribution questions the hiatus most often presupposed but at times also argued in the Pauline letters, between notions of evil and empire from the perspective of Paul's Jewishness.
\end{abstract}

Key Words: Paul's Jewishness; Empire; Powers; Imperial Discourse; Theological Convention; Religion and Politics

\section{Introduction}

In mainstream academic work, neither Paul's Jewishness nor his life under the Roman Empire are still in serious dispute. Increasingly, Paul is re-politicised (political and economic dimensions of his letters) and decentred (towards a people's history), acknowledging the skewing effect of monolithic, retrospective Christian interpretation over centuries (Johnson-DeBaufre, 2012:13-23). However, Pauline letters are often still read as 'Christian' theological treatises, and Paul's Jewishness and life under Empire treated as two unrelated, at best, concerns. How Paul addressed the powers, how he understood their nature and how he related to them are impacted upon by such tendencies. However, his Jewishness within Empire formatted Paul's relationship to power, as much as issues of religion and justice. In short, with Paul's Jewishness in mind, this contribution questions the hiatus presupposed and at times argued in his letters between powers of evil and empire as discrete entities.

\section{Beyond Complacent Conventionalism}

Conventional biblical interpretation, an admittedly broad category, is predisposed to offer theologically-focused readings in the narrow sense of the word, restricting textual interpretation. ${ }^{2}$ Intellectual trends can seldom, if ever, be attributed to a single cause, and while it would be foolish and frankly impossible to deny theological dimensions of biblical texts given their subject matter, the totalising effect of theological interpretations has meant the exclusion of the texts' wealth of meaning. The ingrained theological focus on texts has been ensconced in the academy in established, long-held beliefs in historical objectivity,

Edited version of a paper read at the SBL Annual Meeting (Paul within Judaism-program unit), Atlanta USA, 21-24 November 2015.

2 By theological readings is meant the use of modern theological constructs and frameworks as hermeneutical grids with which to read biblical texts, which tend to slight the texts' historical settings and ignore the history of the texts' interpretation. More appropriate approaches ironically acknowledge the reciprocity between texts and theological interests, then and now, requiring due attention for the impact of the history of interpretation of texts and incorporating their socio-historical contexts. 
and the ability to describe a past as it actually happened. ${ }^{3}$ Indeed, the realisation that the past does not exist outside its literary presentation is a recent and not uncontested position in biblical studies. ${ }^{4}$ Moreover, literary constructions of the past imply recognition for the ideological nature and cultural embedding of historical (re)presentations too. ${ }^{5}$ Intersections of texts, language, culture and politics reach beyond the twentieth century's linguistic turn which initiated such intersectionalities within their various power constellations, to the extent that a 'cultural' or even a 'political turn' has become evident if not yet prominent in NT studies. ${ }^{6}$

Developments constituting the political turn, however, often meet with conventionalist backlash, given long-ranging ideological and epistemological investment and support. ${ }^{7}$ The backlash operates with lingering claims regarding the plain sense or sheer apparentness of shared, conventional concerns regarding the NT texts. Two aspects serve not only to put the conventionalist reaction into perspective but also to formulate the gist of their challenge to the political turn. The first is the claim that NT authors - and our focus here is on Paul had bigger worries than the Roman Empire in the form of the so-called principalities and powers; notwithstanding some acknowledgement that the gods and powers were not necessarily unrelated to the Roman Empire and imperial strategies. Conventionalists also query the subtlety with which the NT engages Empire, questioning the format and nature of understated resistance; notwithstanding some recognition that texts (like inscriptions) subtly pushed back against Empire through existing but re-tuned images. ${ }^{8}$

A recent and forceful expression that the Pauline letters neither consciously nor subtly engaged the Roman Empire is found in the concluding chapter of a volume by Barclay (2011:365-387), provocatively titled, "Why the Roman Empire was insignificant to Paul". 9

3 By and large, academic study of the Bible shares this theological focus even if scholars do not always strive to achieve a theological reading per se, or associate themselves with the results of the interpretation. See the persuasive arguments by e.g. Horsley (2000:72-101) and Schüssler Fiorenza (2000:40-57) in this regard.

4 "History itself, insofar as it is discernible by any human being, is just like a text in that it is constructed by a particular person in a particular time and place. And it must be interpreted like a text. There is, in the end, no escape from language and textuality" (Martin, 2005:18).

5 The ideological aspect of interpretation cuts across the board, e.g. "Of course we must recognise that revolutionary interpretations of Scripture can be [sic] as ideological as interpretations by those in power, just as feminist interpretations can be [sic] as ideological as patriarchal interpretations" (Bauckham, 1989:18). And literary texts are cultural products and therefore part of a larger "inseparable, relational web of residues and artifacts that hang together in ways that are not always easily comprehensible" (Lopez, 2011:80). After all, "history is interpreted according to the mental apparatus and framework we have constructed" (Kwok, 2006:46).

6 See the comments of Martin (2005:1-21) and Stanley (2011:111) in this regard. The political and cultural turns at times go in opposite directions, cf. e.g. Harrill (2011).

7 Conventionalist (rather than traditionalist, although this is no tight distinction) is used to signal the broader biblical scholarly interpretive approach and patterns well-supported by methodology and rhetoric, which tend to establish and maintain a strong theological and at times confessional hermeneutical framework with its obvious limitations and general exclusivist unwillingness to entertain non-conventional hermeneutics or interpretations.

8 Reacting to NT Wright's approach in particular, Barclay raises four concerns regarding Paul's ostensible challenge to the Roman Empire: the peculiarity of Paul's perception of reality, the interpretation of shared terminology, type of reading strategy (or better, assuming coded language in the Pauline letters), and Paul's theopolitical construal of conflicting powers. Barclay is particularly perturbed by the anti-empire approach, to the extent that he violates what he advocates as good exegetical practice, by speculating and, assuming although "proper exegetical method requires us to read precisely what is on the lines" (Barclay, 2011:383).

9 See for example also the earlier arguments by Bryan (2005) that Jesus and the early Christians were critical of the Roman superpower only in as far as the entire biblical and prophetic traditions critique human authority, and Kim (2008) that Paul expressed no anti-imperial criticism. 
The crux of his argument is that "Paul uses different categories and maps the world in different terms" and that Paul saw "only a categorical distinction between the кó $\sigma \mu \rho \varsigma$ and


classifications of culture and power, the world is divided anew around the event of Christ" (Barclay, 2011:384). Smaller matters of disagreement aside, Barclay's (like other coventionalists') penchant to mind-read Paul and in addition, to associate himself indiscriminately with Paul's ostensible intentions, is problematic. My argument, however, proceeds rather from the rhetoric as discerned in the letters ${ }^{10}$ - without doubt still and also an interpretation, but one reliant neither on authorial intention nor on an uncritically affirmative stance towards the Pauline texts or their author.

The two conventionalist concerns, Paul's supposed cosmic struggle ${ }^{11}$ and the lack of explicit oppositional claims, are not unrelated. A long tradition of interpretation that pitched Paul against Jews and Judaism rather than accounting for his Judaism, predetermined the objects of his concerns and opposition. Having so identified Paul's focus, eliminated Roman imperialism as something with which Paul engaged, directly or indirectly, aided by an apparent lack of voicing an anti-imperial stance. The subtle and ambivalent rhetoric which is characteristic of the powerless in hegemonic contexts, where explicit confrontation is impossible, also determines the style and content of the NT texts. ${ }^{12}$ Furthermore, the investigation of the juxtaposition is not made any easier given the different perspectives found in NT documents and the different communities living in the Roman Empire to which they are directed, not to mention different interpretations of such perspectives. ${ }^{13}$ One serious neglect in all this has been proper regard for Paul's Jewish identity in first-century Roman Empire and its implications.

\section{Paul: A Jew living in the Roman Empire}

Paul's life in and engagement with the Empire did not suspend his Jewishness, ${ }^{14}$ as much as his Jewish identity did not put his life in the empire on hold. Unfortunately, at times scholars tend to introduce a choice between dealing with the Jewish orientation and the socalled Greco-Roman context of the NT, implying that recognition of the one excludes the other (cf. Porter, and Pitts, 2013:2). ${ }^{15}$ However, accounting for life in a Hellenisticallyimbued Roman Empire and the inescapable Jewishness of Paul are both crucial for

10 This is in line with a cultural studies approach: "The 'cultural turn' emphasises the inadequacy of reading texts to reconstruct the voices of ancient people, in favour of theorising the discursive strategies in the 'texts' themselves".

11 Barclay (2011:384) is at pains to point out that 'cosmic' should suppose that the powers "hover in some extrahuman sphere, and not (also) in human lives on the earthly stage". However, and notwithstanding his accusation that Wright fails to clarify the relationship between the Empire and the powers, for Barclay the powers are largely metaphysical constructs which may affect Paul's consciousness in redrawing the map of the universe but apparently little else. See also below.

12 See also the use of 'figured speech' in the HB/OT and Quintilian on 'safe speech'.

13 See Moore (2006b:199): “And yet even if Mark lacks the explicitly hostile attitude toward Roman rule evident in Revelations[?], he also lacks the explicitly 'quietist' attitude toward Roman rule evident in at least two other first-century Christian texts, namely, the letter to the Romans (cf. 13:1-7) ... and 1 Peter (cf. 2:13-17)."

14 Some scholars bemoan the continuing influence of 'standard' Western dictionaries and commentaries in TwoThirds World theological school with their often anti-Jewish remarks and warped notions about Christian origins (Levine in Kwok, 2006:59) - a problem exacerbated by outdated but free online materials.

15 For criticism of 'Greco-Roman', particularly in masking the ubiquity of the Roman Empire, cf. Reed and Dohrmann (2013:4-9). 
understanding each of these elements and their influence on his work (Donfried, 2011:48; cf. Kwok, 2006:53-54). ${ }^{16}$

The cultural or political turn in Pauline studies requires a movement away from an essentialist approach to Romanness as some sort of bounded identity. ${ }^{17}$ Rethinking Empire in Paul, then, starts with rethinking Empire as such (Punt, 2012a:1-11). Empire arguably is best theorised as a structural, differentiated, influential, negotiated concept. First, the structural and material reality of Empire comprised a binary principal of centre and margins, with centre symbolised by a city and margins subordinated to the centre - at a political, economic or cultural level. ${ }^{18}$ But second, structurally already Empire was neither singular nor uniform in temporal or spatial senses but differentiated in constitution and deployment regardless of many resemblances. ${ }^{19}$ Third, the reach and power of Empire influenced and impacted in direct and indirect, in overt and subtle ways, on all aspects of life, on the powerful as well as on the subalterns. The unrelenting material presence and ideological influence, traversing other dimensions of first-century life across a geographically spread of communities, suggest two further notions about Empire. Empire, fourthly, was primarily a conceptual entity, fluid and shifting and changing, to which its material form(s) attest - admitting that mutuality between structure and idea does not reverse the conceptual primacy! Fifthly, and contrary to restrictive, essentialist understandings, ${ }^{20}$ Empire can be theorised as dynamic and primarily a process, in conceptualising and constant fabrication: a negotiated concept, co-constructed by all, and not only the powerful (see Punt, 2012a). Harrill contends that "to be Roman was a discourse" expressed in ideology: "language that colludes with, supports, and makes sense of the current structures of authority and domination that a particular society uses to construct its social 'reality' and in which writers can participate even if the collusion is not altogether conscious" (Harrill, 2011:291). ${ }^{21}$ Empire was negotiated in dynamic ways, not as static positions 'for' or 'against' - interaction was more complex and hybrid than simple support or resistance. ${ }^{22}$

16 “Once Paul's Jewish moorings became more manifest, his counter-Roman posture could become more obvious. Paul had first to be re-constituted in terms of his Jewish 'apocalyptic' theological framework, and its special Judeo-Messianic religio-politics” (Zerbe, 2012:15; also White, 2009:316-333, focusing on Daniel). For possible connections between imperial rule and patriarchy, see e.g. Kwok (2006:59), "the Jesus movement must be recognised as a movement within the context of Judaism, and postcolonial feminists are interested to know if this movement provided opportunities for Jewish women to challenge not only patriarchy but also imperial rule".

17 Theodor Mommsen's late nineteenth century's 5 volume work on Roman history is often cited as a most influential text for the notion of being 'Roman' as a "clearly bounded identity in cultural opposition to 'native', and 'Romanisation' to be an active (top-down) force to which natives 'reacted'" (Harrill, 2011: 290-291).

18 Other binaries follow: civilised/uncivilised; advanced/primitive; cultured/barbarian; progressive/backward; developed/undeveloped or underdeveloped. In the discussion of Rome and its role and impact on the communities of the early followers of Jesus, the city of Rome constitutes such a metropolitan or rather imperial centre; western and in particular eastern parts of the ancient world, including subcontinents such as Asia, were deemed peripheral areas (Friesen, 2001:17).

19 Empires are imperial in distinctive ways, differing e.g. in terms of power base, duration, spread and influence (Walker, 2002:40).

20 Choosing against essentialising empire does not imply a disavowal of real life, flesh and blood entities (so e.g. Roth, 2003), but points to the illusionary nature of sure categories (essentialism) and certain grounds (objectivity) (cf. Brown, 2001:44), i.e. to view social phenomena in terms of trans-historical essences, independent of conscious beings, disallowing the notion that society or people determine the categorical structure of reality.

21 See also Oakes (2005:302-303): "By 'Rome' I mean, primarily, Roman ideology, that is, Roman discourse which sustains certain power relations. The power relations in question are those of Roman society. They have both external and internal dimensions. Externally, they constitute Rome's dominant position over against any 


\section{Paul the Jew}

As much as Paul negotiated (with) Roman Empire as ideological discourse, he was informed by his Jewish context and frame of mind. ${ }^{23}$ For some scholars Paul's Jewishness counted against anti-Empire notions in his letters. Seyoon Kim argues for a general dissatisfaction with a world not acknowledging God, "a general criticism of the pagan world under their rule as idolatrous, immoral, unrighteous, perverse, and hopeless". But Kim (2008:64) finds in Paul no critique of the Empire, emperor worship, political repression, military violence, imperial conquest of other peoples, or economic exploitation. ${ }^{24}$ For others it is not so much the Jewish Paul's concern with paganism which mitigates against an anti-Empire stance, but that he followed the biblical tradition's alleged pragmatism in aligning human power structures and divine purpose. Biblical tradition is taken as concerned not with forms or origins of human power structures, but with their purposes and that the powerful live up to these purposes. ${ }^{25}$ Generalising and locked into a one-sided theological position, Bryan (2005:125) claims that the Bible sees human authorities in service of God, "promoting God's peace and God's justice for all", but also that authorities' very existence is by the will of God. ${ }^{26}$

However, Paul's Jewish frame of reference and his ambivalent position to politics can be construed differently. Paul's political theology was essentially Jewish, not unlike that of the prophets. Paul's Jewishness can be seen to determine his anti-Empire stance: "The more Jewish we make Paul's 'gospel', the more it confronts directly the pretensions of the Imperial cult, and indeed all other paganisms whether 'religious' or 'secular" (Wright, 1994:228). ${ }^{27}$ Wright identifies wide-ranging political claims made in the Scriptures of

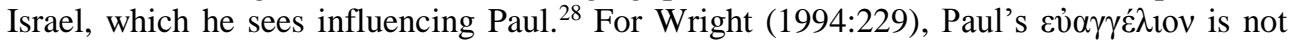
only grounded in Judaism, but also and as a result, a "royal announcement which

competing powers. Internally, they constitute a hierarchy that runs from the emperor down to the most marginal inhabitants of the Empire. Alongside ideology, I am including practices that maintain the power relations in question".

22 Modern empire theory provides further useful categories for theorising the Roman Empire of the first century, but space does not allow much further discussion here; suffice to mention the importance of the conceptual nature of empire, of borderlessness, psychological impact and claims upon world peace (Hardt \& Negri, 2000:Xv). At the heart of imperial peace is violence, ably supported by the military and various other structures, systems and manifestations of violence (cf. Punt, 2012b), and the position of Roman emperors and elite depended on their perceived ability to inflict violence (Mattern, 1999).

23 Barclay seems to suggest that scholars pursuing the link between Paul and Empire make them guilty of disrespecting the fact that Paul's "angle of perception on the Roman world was different from ours" (2011:375) - not accounting for a similar counter-accusation that can be directed at his conventionalist approach, not to mention the loaded 'ours' which betrays his assumptions and presuppositions.

24 Texts such as Rom. 1:18-31; 12:2; 1 Cor. 1:18-25; 6:1; Phil. 2:15; 1 Th. 4:13 are cited; adding "[a]t most Paul points to the total inadequacy of the much-celebrated pax Romana (1 Th. 5:3) and of the Roman commonwealth and its soteria (Phil. 3:20-21)" (Kim, 2008:64).

25 "Thus, the biblical tradition subverts human order not by attempting to dismantle it or replace it with other structures but by consistently confronting its representatives with the truth about its origin and its purpose" (Bryan, 2005:125).

26 The harshest criticism Bryan sees in the Bible is that "[p]owers and superpowers are allowed to exist, and may even be approved, but they are always on notice" (Bryan, 2005:125).

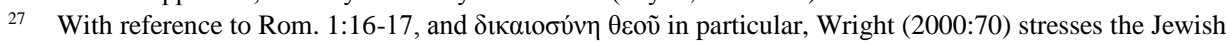
context of Paul's work which clarifies the meaning of the phrase as God's own righteousness.

28 "According to this covenant faithfulness, as we can see in the analogous theological wrestlings of 4 Ezra, the God of Israel must somehow not only be true to the covenant promises but also remain impartial, with no favorites. This God must also not only deal properly with evil but rescue the helpless. This God must ... act as the righteous judge in the cosmic law court" (Wright, 1994:229). 
challenges the pagan principalities and powers". ${ }^{29}$ As a Jew Paul did not retreat from the powers, resigning them as evil manifestations of paganism to the wrath of God, but challenged them as integrally connected to the everyday political context enveloped by the Empire's long shadow. The intersection between Paul's Jewishness and his experience of Empire raises the question whether Rome was considered part of the power of evil, and whether a Jewish frame of reference erased the Roman Empire and its various authorities from the constellation of powers? $?^{30}$

\section{Paul and the Powers}

Pauline scholars of all persuasions readily admit to Paul's deep-set concern with evil powers, but differ widely on what these were, with opinions ranging from spiritual entities to civic authorities. ${ }^{31}$ The letters mention $\alpha \rho \chi \alpha i$ (Rom. 8:38; 1 Cor. 15:24; Phil. 4:15), ${ }^{32}$

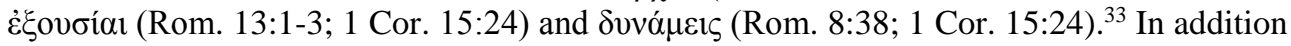
to these broader and ambivalent terms, some related terms are used, generally but not necessarily denoting earthly rulers or civic authorities. ${ }^{34}$ 'A $\rho \chi 0 \nu \tau \varepsilon \varsigma$ (rulers) refers to earthly rulers, who among others collect taxes (Rom. 13:3); but scholars differ on whether 1 Cor. 2:6, 8 refers to earthly or to spiritual rulers. ${ }^{35}$ Paul also refers to "many gods and many

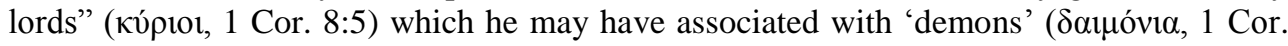


Col. 1:16; Eph. 1:21) may have developed. ${ }^{36}$ The all-inclusive phrases Paul deploys in

29 The correspondence in use of terms such as $\sigma \omega ́ \tau \eta \rho, \pi i ́ \sigma \tau \iota \varsigma, ~ \varepsilon i \rho \eta ́ v \eta ~ a n d ~ w o r d s ~ w i t h ~ t h e ~ \varepsilon u ̉ a \gamma \gamma \varepsilon \lambda$-stem not only in contemporary Empire but also in the LXX, is often taken to indicate significant Jewish influence and even aims, in Paul's communication (e.g. Fantin, 2011:44). Fantin (2011:11) also argues that "the title [кúptos] was common for God in the Septuagint, which undeniably influenced Paul".

30 For (Barclay, 2011:371 n32) "the relationship between the Roman empire and the 'principalities and powers' is not fully clarified in Wright's work". The danger lurks that recognition of the letters' subversive stance towards Empire may lead to scholars' (inadvertently, perhaps) severing Paul's relationship with Judaism (e.g. White [2009] who has Paul radically alter the Jewish apocalyptic framework).

31 Such terms of course do not always denote the omnipresent and actual cosmic, supernatural powers but also

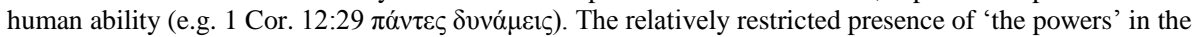
Pauline letters augurs against making these Paul's focus of attention. "Within the Pauline corpus only four letters use these terms in contexts implying that they are nonhuman powers (excluding for the moment the more problematic stoicheia tou kosmou, 'elements of the world,' which appear twice in both Galatians and Colossians): Romans, 1 Corinthians, Colossians and Ephesians” (Reid, 1993:747).


Theodotion's version using $\alpha \rho \chi \alpha i$.

33 The prevalence of these terms in the deutero-Paulines (Eph., Col., Pastorals) is probably an indication of how the Roman imperial rule was gradually 'spiritualised', not in the sense of metaphysical powers but in moving away from the alignment of real-life oppositional forces with metaphysical forces, so that the latter came to rule the day. Powers-terms are used with various meanings in the Gospels and Acts.

34 It is only when Paul's principalities and powers are perceived as spiritual that $\alpha \gamma \gamma \varepsilon \lambda \mathrm{ol}$ (Rom. 8:38) is also listed. Cf. Reid (1993:749).

35 Reid (1993:747) argues strongly for Paul being influenced by Daniel (especially Dan. 10:13, 21; 12:1 LXX), "the Danielic cosmology of spiritual powers lying behind the nations", where ö $\rho \chi 0 v \tau \varepsilon \varsigma$ translates the Hebrew śarîm (chiefs, princes, captains or rulers) as malevolent contemporary spiritual powers (the positive sense of śar as angelic 'Ruler/Prince of Light' coming to Israel's defence against the Satan or the Angel of Darkness, is found in 1QM 13:10; 1QS 3:20). However, are the apocalyptic frameworks of Daniel and of Paul similar enough to compare the referents denoted by similar terms in their work?


opinions are divided on whether it refers to "basic principles of religious teaching such as the Law", or to "essential, rudimentary substances of the universe such as earth, water, air and fire" or to another category of powers, namely "personal spiritual beings of the cosmos such as demons, angels or star deities" (Reid, 1993:229). Reid (1993:232) prefers seeing this phrase "as a broad, inclusive term that embraced the whole 
Rom. 8:39 and Phil. 2:10 (cf. Col. 1:16 and Eph. 1:21) include a wide-ranging array of powers and spatialities. In Phil 2:10 an intertextual echo of Isaiah 45:23 evokes the Scriptures of Israel's apocalyptic notion of enforced submission to earthly powers (cf. Is. 45:24 and 24:21; cf. Reid, 1993:749).

Powers were prominent in the Greek and Hellenistic world where the distinction between a cosmic principle and divine figure was not always clear. References to a god's power was unnecessary in a context where the god as such is power. Individual gods were $\delta v v \alpha ́ \mu \varepsilon ı \varsigma$ of the cosmic, universal dynamism and represented impersonal and disinterested divine figures' abilities. ${ }^{37}$ In fact, in Hellenism the world itself was constituted by and through forces, which people needed to know and in which they needed to participate, in order to live (Grundmann, 1985:187). Paul's Scriptures knew the power of a personal God, which replaced neutral forces of nature that were equated with deity. ${ }^{38}$ In Second Temple Judaism the Scriptures' emphasis on God's power as demonstrated in the exodus was heightened by the Maccabean deliverance. In NT times, emphasis shifted to eschatological deliverance (see already Isa. 2:19; Ezek. 20:33), with daily life as a battlefield of good and hostile forces inhabiting the space between God and people. God's supremacy remains intact, however, and God's essence is found in God's power. ${ }^{39}$

Conventionalist interpretations of a particular ilk see the principalities and powers as ethereal powers, that is "a spiritual dimension of the created order (objective and personal powers, some would add) who, being inimical to Christ and his church, were in some way opposed and either neutralised or conquered by Christ" (Reid, 1993:746). ${ }^{40}$ Granted, the assertion that Paul refers to spiritual powers does not mean to imply that they are unreal or assume the form of cloud-floating angels (e.g. Carr, 1981) or demonic forces from hell (e.g. Arnold, 1992 $)^{41}$ - at least, generally not only heavenly or ethereal entities. ${ }^{42}$ A prominent voice on the powers in Paul, sees the powers as "heavenly and earthly, divine and human,

host of spiritual beings known individually as principalities, powers, dominions and rulers, the equivalent to the angels or gods of the nations."

37 As Fredriksen (2006:598) explains about ancient religions and their gods, "While lower gods with visible bodies might seem more involved with time, the highest god, their ultimate source, lay beyond both time and matter".

38 As Grundmann (1985:187) explains, in the Scriptures the focus is not on power itself, as independent entity, but rather "the will which it must execute and serve." As all demonstrations of divine power, the exodus event rules supreme (e.g. Ex. 15:6, 13; 32:11; Dt. 9:26, etc), with Dt. 3:24 as typical of its significance and with many indications (e.g. Neh. 1:10; Is. 10:33) that similar future events are not precluded.

39 The importance of the Law cannot be overrated in this regard: "As regards the saving power of God, it is found in the law. The strength that God gives his people is none other than the law. By the law he creates the world, directs his people, and gives sanctification and power to those who obey it. The law is thus saving power as the revelation of God's will" (Grundmann, 1985:188).

40 Such a conventionalist reading is often informed by a "Christianising theory of religion which assumes that religion is essentially designed to provide guidance through the personal crises of life and to grant salvation into life everlasting imposes on the imperial cult a distinction between religion and politics" (Price, 1984:237).

41 For Arnold (1992:467), principalities and powers "designate angelic beings, both good and evil, but most commonly in reference to the realm of Satan. Several other terms are used in conjunction with these to denote supernatural beings: exousiai ('authorities'), archōntes ('rulers'), thronoi ('thrones'), kyriotētes ('lordships'), kosmokratores ('world rulers'), and stoicheia ('elemental spirits')".

42 "[A] particularly influential line of interpretation has been that Paul demythologised the powers and employed the language to refer to the structures of earthly existence such as tradition, morality, justice and order (Berkhof). This approach has been adapted by others who have argued that Paul was referring to both the socio-political structures of society and spiritual forces behind and within those structures (Yoder, Mouw)" (cf. Reid, 1993:747). 
spiritual and political, invisible and structural" (Wink, 1984:100; also Wink, 1992). ${ }^{43}$ The powers are psycho-spiritual webs constituted through collective human belief and energy, since the spiritual powers are "the inner aspect of material or tangible manifestations of power" (Wink, 1984:104).

In yet another version of conventionalist response, Barclay holds that Paul purposely refrained from defining the powers, either as physical or spiritual entities, according to

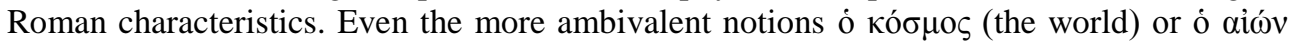
(this age, 1 Cor. 1-2; Gal1. 4) with which he referred to political rulers (1 Cor. 2:6-8) and

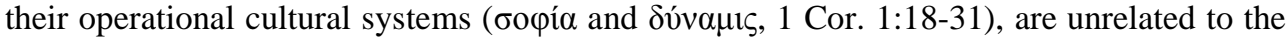
Roman Empire, according to Barclay. Principalities and powers "are entities which defy our normal taxonomies": more than 'anthropological', principalities and powers extend across all of life, "from death to social disintegration to the corruption that infests the whole cosmos (1 Cor. 15:26; Rom. 8:18-39)". The furthest that Barclay is willing to allow the powers to be reflective also of civic authorities is his admission that "Paul's language of the 'powers' thus denotes comprehensive features of reality which penetrate (what we call) the 'political' sphere, but only as it is enmeshed in larger and more comprehensive forcefields" (Barclay, 2011:384). ${ }^{44}$

Literary, cultural and political turns in NT studies are hampered, however, by a conventionalist modern worldview to textual reference. Historical objectivity and the ability to describe the past as it actually happened, are making way for the realisation that the past does not exist outside its literary presentation. Searching for literary references to Empire and emperor are akin to the search for earlier or contemporary texts in order to explain other NT texts. The assumption is that other texts, or in our case, Roman realia are present only in as far as these are directly referenced. But imposing concerns of Western novelists onto ancient texts smacks of anachronism. The problem is complicated further, though, in that such "domestication of the language" fails to recognise how in the high-context ancient Mediterranean society, texts often took "for granted large amounts of information" (Hobbs, $1995: 252) .{ }^{45}$

\section{Pauline Negotiations: Powers and Empire}

History shows how the exertion of dominating power was met in the past by resistance. In the first century, too, resistance sprung up from anger and resentment and took various forms, only occasionally open revolt. ${ }^{46}$ In its negotiation of Empire, the Pauline letters, too show resistance against contemporary, Roman-aligned symbols of domination. The letters'

43 Particularly focused on interpretation for the contemporary context Wink points to governments and corporate conglomerates as powers (Wink, 1992): it is not the material nature of these entities that constitute them as powers, but rather their existence as spiritual entities. People are enslaved to the powers through their allegiances to them, blind to their violence and evil aims and participation in the contagious cycle of violence. Since the powers are not recognised as such, and with people's buy-in, the powers develop lives of their own and dominate the very people who made them into powers in the first place.

44 Zerbe also argues that "Paul refuses to dignify Rome by naming it specifically" and that Paul "is hesitant to give Rome too much credit", and that "Paul's move, rather, is to place even Rome under the ultimate sovereignty of God" (Zerbe, 2012:25).

45 Drawing on the work of Jacobs-Malina (1993), Hobbs asserts that "the military metaphor presents a decisive shift in the self-understanding of at least a substantial part of the primitive Christian community" (Hobbs, 1995:255), a development or a corrective depending on one's chronology of the NT documents.

46 Against uneven odds, protest took public forms "such as pilfering elite property, evading taxes, working slowly, refusing to work at all, or attacking a symbol of domination” (Carter, 2006:11). See also e.g. Crossan (2007), Freyne (1988:50-68), Horsley \& Hanson (1985). 
stance is ambivalent, not unlike such negotiations in other hegemonic contexts. A choice between pro-Empire or anti-Empire readings is insufficient to make sense of the letters and inappropriate to both the literature and socio-historical context. Crude oppositional models which entertain only support or subversion are inadequate. ${ }^{47}$ The alternative to avoiding this impossible choice is, however, not "a perspective which reads political history according to a different script" (Barclay, 2011:386) - a more plausible alternative approach is not to divorce politics from religion but rather to explore their intersections in the first century.

\section{Folly of separating Politics and Religion}

The Pauline letters' negotiations with Empire are framed by the intersection between religion and politics. Imposing the modern, conventional distinction between religion and politics onto this context, conceals the basic similarity between politics and religion: "both are ways of systematically constructing power" (Price, 1984:237). ${ }^{48}$ Furthermore, unlike today's religion in the sense of a system of beliefs or impersonal pattern of ritual actions, cult was the better term in the first century Mediterranean world: "those rituals and offerings whereby ancients enacted their respect for and devotion to the deity, and thereby solicited heaven's good will”. Individual households, and at times individuals themselves, practiced their versions of piety, but worship was generally public, communal and political (at civic and imperial levels). ${ }^{49}$ While modern religion focuses on the inner disposition of the believer in the sense of 'psychological states' or even 'sincerity of belief', ancient 'religion' in contrast focused on acts: "how one lived, what one did, according to both inherited and local custom. Ancient religion was thus intrinsically communal and public: performance-indexed piety" (Fredriksen, 2006:590). ${ }^{50}$

The role of the priestly elite in and around the Jerusalem Temple illustrates the intersection of religion, politics and economics in the first century. Rome did not expect of its conquered subjects to drop their religious affiliations, but to broaden them to accommodate also the Roman gods and sense of religiosity or at least to tune local cults so as that they show support for the Roman cause (see Carter, 2006:66). And so it is little surprise that the priestly elite generally sided with the Romans when unrest broke out, since their loyalty ensured that they retained their power and privileges. In ways similar to the Roman and Herodian elites, the priestly elites obtained their wealth through tithes and sacrifices made by people to the Temple. The priestly elite acted at the same time as patrons on behalf of God and as subjects to the Roman Empire. ${ }^{51}$

47 Cf. e.g. the section on "Christianity and the Roman world" in Cobb (2008:11-17) which hinges on a choice between appropriation and subversion. Portrayals of the relationship shows the endurance of a conflict model (see Punt, 2015).

48 As Galinsky (1996:288) convincingly argued, "Fundamentally, religion is a response and alternative to chaos; it is an attempt to provide structure, order and meaning, the very efforts that lay at the heart of the Augustan reconstitution of the res publica". See e.g. also in Sib Or 3.545-555 for religion as mechanism to acculturate and control subject peoples.

49 Recent interpretation of literary and archaeological remains indicate that Roman emperor worship was a public enterprise but that the current emperor was likely worshipped fairly widely in domestic cults within household contexts. Cf. Gradel (2002:198-212). The value of emperor worship is hard to overestimate, as Price (1984:248) argued, "The imperial cult stabilised the religious order of the world".

50 The presentation of incipient Christianity stressing faith and dogma misrepresents religion in Roman times. Religious forms were about actions, performing state and local rituals to appease the gods, even if (see Versnel, 2011) ancient religions were not totally devoid of beliefs. If Christianity's emphasis was on faith as action and content, it may have seemed pointless to many, or might have been seen as endangering traditional human relationships with gods.

51 The Jewish elite's attitude towards the Empire may have been the result of a longer period during which non- 
In this context, the Pauline letters ${ }^{52}$ were "by no means 'apolitical' - neither privatised, confined to the level of individual piety, nor spiritualised, detached from the social and political realities of everyday life" (Barclay, 2011:385). However, to claim that Paul's theology did not relate to the Roman Empire "because his systemic analysis of the world differs from ours" (Barclay, 2011:385), is misleading. This last phrase is instructive since it is both Barclay's conventionalist theological framework as well as a truncated understanding of Empire as primarily a matter of structures and systems rather than ideological, negotiated concept that sees his analysis go astray. ${ }^{53}$ As Milnor (2005:4) puts it, "It is no longer necessary to think of the early Empire as a time of totalitarian oppression, when Rome suffered under the imposition of a unitary and uncompromising ideology; rather, we now may understand it as a concept, whose power lay in its ability to set the terms which framed any discussion of politics, society, and culture". ${ }^{54}$ With overpowering Roman ideological control, relegating Paul's powers and principalities to the spiritual realm, emptying them from human elements (authorities), does not make sense. Political and religious intersections short-circuit claims that Paul's principalities and powers would have excluded Roman (aligned) authorities or that Roman (aligned) authorities shrink into insignificance given other principalities and powers. If nothing else, Rome was an evil power, at least, another evil power. God's unrecognised sovereignty led to misplaced loyalties (Rom. 1:1832) including to idols or images - likely also of the emperors - which were dwelling places of demons (1 Cor. 10:20-21). ${ }^{55}$

\section{Rome as Evil Power}

Paul's perspective identified a world not ordered to God's purposes, a world under Rome's power. The flipside of disavowing God's role in the world, was allegiance to ruling powers hostile to God: sin and death (Rom. 6:9, 14); flesh (Rom. 8:7); and Satan (Rom. 16:20). But the present evil age that stood in contrast to the coming age of God's reign, was under Rome's rule (Gal. 1:4), and 'ungodliness and wickedness' defined the present age (Rom. $1: 18$ ) and its ostensible wisdom was actually foolishness (1 Cor. 2:6). The rhetoric makes for "a scathing condemnation of Rome's hierarchical, exploitative, and legionary empire" (Carter, 2006:87). ${ }^{56}$

Still, conventionalist denial separates Paul's denunciation of the principalities and powers from anti-Empire critique. "The true enemies were no longer the Romans, but the

cultic honours were bestowed upon the Romans in synagogues (e.g. Philo, Flacc 49, Legat 132) and sacrifices made for the emperors in the temple (Josephus, Apion 2.76-77, 409-410, 412-417; already the case for Hellenistic rulers, e.g. 1 Macc. 7:33; Arist 45) - within certain limits.

52 Barclay actually writes 'Paul's theology' - but this concept calls up further questions which cannot be addressed here.

53 One cannot help but wonder, is Barclay's acknowledgement that it is impossible to separate Paul's theological and political ideas truly reflected in how he interprets Paul? He argues in a way that elevates matters theological to overshadow everyday concerns.

54 However, in similar vein to 'the Age of Augustus', imperial culture was a developing concept rather than 'chronological moment'; it requires attention for its "creation as a process, and its historical role as a gradually imagined 'fact' which transformed how Roman politics and society would be understood" (Milnor, 2005:5).

55 According to Paul's analysis, not acknowledging God leads also to caustic destructive social relationships (Rom. 1:29-31). As for imperial images, Ando (2000:237) argues, "The ability of portraits to demand veneration, as it were, made them active forces within local affairs. They were instruments of power, and, in representing a unique mortal with superhuman power, they became powerful and animate in their own right". The notion that the Empire is in the power of the devil, and that Empire embodies the devil's power is found explicitly in Mt. 4:8-9; Lk. 4:5-7; and Rev. 12:9 also (cf. Carter, 2011:143). 
spiritual powers that lurked behind the human faces of the authorities and empires of this world" (Reid, 1993:750). Jewish indignation at the Romans' occupation and violation of the sanctity of Temple, Torah and sacred territory, is seen exclusively as theodicy and not a social or political problem. ${ }^{57}$ In short, "[t]he powers also populate the backdrop of this drama of redemption: appearing among the potential barriers to the love of Christ, they are, nonetheless, ultimately powerless to thwart the final triumph of Christ (Rom. 8:38)" (Reid, 1993:751) ${ }^{58}$ Pauline texts, exemplified already by the basic claim that the "the rulers of this age" were responsible for Jesus' death (1 Cor. 2:8), counter such claims. Debating whether rulers refer to heavenly powers or human rulers, it is probably another instance where both the overt role of the imperial authorities and the concealed work of supernatural powers are joined (Carter, 2006:88). ${ }^{59}$

Conventionalist argument cannot prevail against the overwhelming sense that powers could not have excluded Roman authorities altogether, given Paul's Jewish setting. Philo

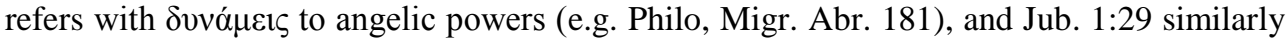
to "powers of the heaven" (cf. links between heavens and armies in 1 En. 61:10 and 2 En.

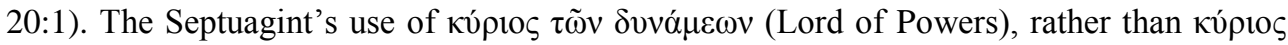
$\tau \tilde{\omega} \nu$ $\sigma \tau \rho \tau \tau \tilde{\omega} \nu$ (Lord of armies) for Yahweh Sabaoth (Lord of Hosts) may be indicative of Jewish texts' use of $\delta v v \alpha ́ \mu \varepsilon 1 \varsigma$ for military power (e.g. Ps. 102:21; Wink, 1984:159-61). "This militaristic association suggests that the same connotation might be present in the use of dynameis in Romans 8:38 ... where the powers are opposed to God" (Reid, 1993:748). While "Rome is not the chief or sole enemy to be overcome in Paul's theological rhetoric" (Zerbe, 2012:24), it is not excluded from the constellation of powers that his letters confronted.

Some scholars insist that Paul did not consider the Roman Empire as part of the spectrum of evil power in the world; that it was not on Paul's radar. ${ }^{60}$ Largely repeating the notion developed by Oakes (2005:301-322; see Barclay 2011:387) that Paul remapped the universe through Christ, Barclay concludes: "Paul's gospel is subversive of Roman imperial claims precisely by not opposing them within their own terms, but by reducing Rome's agency and historical significance to just one more entity in a much greater drama"

57 The War Scroll of Qumran (11QM, 4QM491-496) apocalyptically expands on the eschatological battle of Dan 11:40-12:3, depicting a war in which righteous of Israel ('Sons of Light', assisted by Michael and the angelic forces) defeat the 'Sons of Darkness' (assisted by Belial and his powers of darkness). Defeating first the traditional opponents of Israel (Edom, Moab, Ammon, Philistia, 1QM 1:1-2), the final battle is fought against the 'Kittim of Asshur' (1QM 1:1-14; 11:11; cf. Num. 24:24). The Kittim is generally understood to refer to the Roman occupation of the first century (Reid, 1993:749).

58 "The immediate context of 1 Corinthians 15:24 leaves no doubt about whether Paul ever spoke of the powers as being evil, for there they are listed among the eschatological 'enemies' (echthroi, 1 Cor. 15:25-26; cf. Eph. 6:12), including death" (Reid, 1993:751).

59 "Paul's proclamation of 'Christ crucified' (1 Cor. $1: 23 ; 2: 2$ ) reveals the profound antipathy between God's purposes, expressed in Jesus, and the imperial world. Its rulers employ violence to protect their order and power against Jesus' threat. Jesus undergoes the fate of many enslaved by the emperor who dare to envisage a different order (Phil. 2:7)" (Carter 2006:88). Cf. Arnold (1992:467): "Deeply aware of the influence of "the god of this age' (2 [JP] Cor. 4:4), Paul sees demonic rulers (archontes) as ultimately responsible for the death of Christ (1 Cor. 2:8; see Eph. 2:2 for a similar use of archon as an evil spirit being). These powers did not understand the wisdom of God, who would use Christ's death for the actual defeat of the realm of evil and thereby procure salvation for his people".

60 Barclay seems more intent on refuting NT Wright's claims that in a carefully camouflaged way (hidden transcripts) Paul challenged the Roman Empire on their claims pertaining to imperial beneficence. Possible problems in Wright's position can be identified, but Barclay hovers on making a caricature of it, with references to "simple anti-Roman propaganda in Paul" (Barclay, 2011:18) and similar quips! 
(Barclay, 2011:386). ${ }^{61}$ This position is one that Schüssler Fiorenza (cf. Polaski re choosing in which moment to read $)^{62}$ identifies as male-stream, siding with Paul as much as with conventional scholarship that finds in him a 'true radical'. ${ }^{63}$ The comfort of a long interpretive history apparently dissolves the need for the acknowledgement of grey areas and (marginal) contradictions. ${ }^{64}$ However, the recognition that powers in the Pauline documents included also Roman agents, is not the final word since the Roman imperial context rubbed off on the letters as Paul negotiated Empire, as is evident in Paul's rhetorical negotiations with Empire.

\section{Paul's Rhetorical Negotiations of Empire}

Pauline negotiations of the Empire cannot be adjudicated by individual references or explicit counter-claims against it, but rather in analysis of his rhetoric. ${ }^{65}$ It moves discussions beyond stale pro-, anti-, or non-Empire arguments and simplistic notions regarding Rome's possible (covert or otherwise) inclusion in the powers and principalities. Better analytical or reading frameworks than the current logo-centric approach typical of historical critical studies are required. Postcolonial analyses are particularly helpful for analysing rhetoric used in hegemonic contexts characterised by uneven power relations, ${ }^{66}$ and "focus on the impact of the empire, both ancient and modern, and on its representations in the text" (Kwok, 2006:59). Merely focusing on ostensible anti-Empire claims in the Pauline corpus is not impossible but one-sided, since Paul's imperialist counter-claims show the extent to which he lived in and negotiated an imperialist setting characterised by political hegemony and unequal power relations. ${ }^{67}$ In a context where "[t]o be Roman was a discourse, particularly about the nature of authority and power" (Harrill, 2011:291), Paul's rhetoric cannot be divorced from the prevailing political structures or context. ${ }^{68}$ While imperial rule had

61 This is a rather ironic conclusion in view of Barclay's vehement opposition to Wright's use of Scott's notion of hidden transcripts, or the subtle ways in which subalterns ideologically resisted imperial overlords, of which 'the silent treatment' was one version.

62 Contemporary interpreting communities need to choose the moment in which to interpret texts, choosing whether to align themselves with an authoritarian role claimed by Paul, or that of dependency required of the communities addressed, but also whether the particular attitude accompanying the role is appropriate today (Polaski, 2005:80-81).

63 Romanisation can have as skewing an effect as an andro-centric or patriarchal reading of Pauline texts. Questioning the scholarly tradition of Romanisation with the perceived benefits of Roman rule emphasised and its brutality and domination of other people slighted is becoming more pointed (e.g. Mattingly, 2011). In Barclay's (2011) essay, notwithstanding his resolute refusal of any anti-Empire trends in Paul, he claims that Paul is also radical and in opposition to the governing authorities; marginal contradictions in his essay include his focus on a 'theological Paul' yet insisting that in the first century religion and politics were inseparable.

65 Is what Paul says about glossolalia in 1 Cor. 14:10-11 perhaps equally applicable to the rest of his rhetoric?

66 Sharp (2013:45) claims: "Postcolonial criticism refuses the claims, overt predations, and oppressive gestures of empire: namely, cultural discourses and pragmatic actions (military, social, political) that seek to establish the 'naturalness' and beneficence of imperial rule over against supposed primitive, immoral, benighted, or ineffective characters of indigenous colonised persons and native cultures".

67 Not only Paul negotiated empire: “A postcolonial interpretation will highlight the roles these religious leaders played in maintaining the traditional ways of Jewish life, while also serving as mediators between the Jewish people and the Roman order" (Kwok, 2006:59).

68 Harrill (2011:297, following Galinsky) proposes that for the influence exerted by Empire on Paul and in which Paul shared, the term auctoritas, which denoted a person's actual power as granted by subordinates and colleagues, is actually a more appropriate depiction than propaganda. "The ancient value of auctoritas was deeply moral, belonging to the Roman conflict milieu of masculinity, and routed power through the patterns of personalised influence rather than through abstract institutions" (Harrill, 2011:297). Augustus (and his successors) expressed imperium (power) through auctoritas (Harrill, 2011:298). See Horsley (1997:15) for 
shaped and changed Jewish cultures and customs, Paul's Jewishness impacted also on his perception of the Romans. ${ }^{69}$

Some scholars argue that Paul's letters contain a polemic, in the sense of "a communicative act that challenges and/or gives offence in the form of a challenge to another", or "a challenge of one party to another through a claim to a role held by the other" (Fantin, 2011:9). ${ }^{70}$ Others (e.g. Harrill, 2001) present a portrait of Paul that is not held captive by centuries' long tradition of interpretation but with a willingness to explore Paul within his own context. Harrill paints Paul not as subversive but, to the contrary, as a person who bought into and availed himself of the Roman discourse of the day. Paul's allegiance to imperial discourse should not create the impression of allegiance to Empire as such, as the opposite is true. This tension can be explained as the push and pull of Empire, ${ }^{71}$ in a context characterised by hegemony, that is, domination by consent (Gramsci) entailing the active involvement of subjugated groups in their suppression. ${ }^{72}$ Pauline rhetoric infused by a Jewish perspective and availing himself also of Roman discourse at hand, is replete with power terminology. ${ }^{73}$ His claims to power were not weakened by appeals to weakness, and

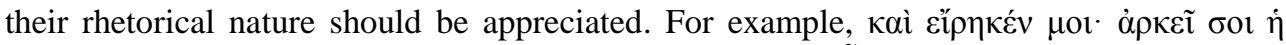

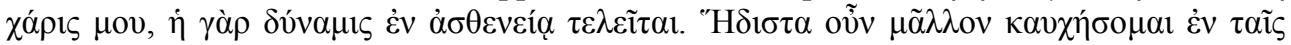

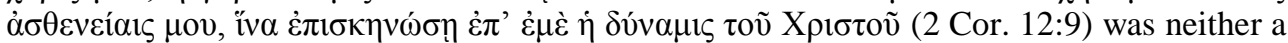
capitulation nor a defaulting to God, but a strong rhetorical claim based on reversals of power - very much a claim upon power itself (see Punt, 2013). ${ }^{74}$

Paul wrote back against Empire, but did not shy away from imperial terms as is evident

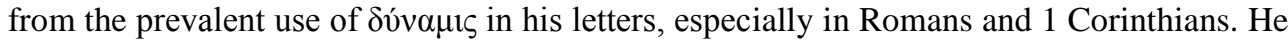
claimed power ( $\delta v \dot{v} \alpha \mu 1 \zeta$ ) with reference to God, and to some extent Christ too. It is instruct-

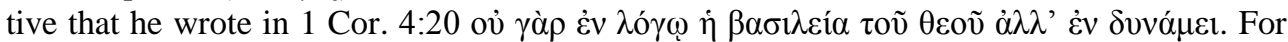
Paul, the kingdom of God also is defined in power, with no room for other kingdoms;

Augustus' auctoritas.

69 “Accepting Taubes's emphasis on Paul's radical political challenge to the Hellenic political world, as well as to the imperial organisational matrix with Rome at its center, we argue that this challenge was performed first and foremost through the 'conversion' of Romans, Corinthians, and Galatians into gentiles" (Rozen-Zvi \& Ophir, 2015:40).

70 Fantin (2011:9) is keen to demonstrate Paul's polemic with Roman emperor worship in particular, focusing on the use of kúptos.

71 See Punt (2012a). Part of the difficulty to speak truth to power in an imperialist setting results from the distance between the powerful and the people. The upper class had little if any interaction with people, having devolved disciplinary power to the indigenous elites and their accomplices. "The possession of Roman culture was another symbol of the status of a community and its leading members, many of whom continued to use the vernacular as the language of common discourse. Roman rule accentuated rather than broke down the divisions between city and country, rich and poor, local elites and the urban and local masses" (Garnsey \& Saller, 1987:203).

72 "In such cases ... the indigene's desire for self-determination will have been replaced by a discursively inculcated notion of the greater good, couched in such terms as social stability ... and economic and cultural advancement" (cf. Moore, 2006a:101), even if the numerical advantage of the oppressed over those in power may neutralise the oppressor or army of occupation.

73 In the words of Seesengood (2005:3): "Colonial encroachment and hegemony are ambivalent; it brings both oppression and opportunity".

74 'But he said to me, 'My grace is sufficient for you, for my power is made perfect in weakness.' I will all the more gladly boast of my weaknesses, that the power of Christ may rest upon me" (2 Cor. 12:9). Often in the midst of his claims of disinvestment of self, patronal power patterns emerge by which Paul claims control (cf. Polaski, 1999:104-123). E.g. his weakness discourse cannot be read simply as a theological argument, since it forms a vital part of Paul's challenge to the social and imperialist setting of his day (see Punt, 2013). 
certainly not for another kingdom making similar ultimate world-conquering claims such as the Roman Empire did.

\section{Conclusion}

Paul's Jewishness and indebtedness to contemporary culture, which included his unavoidable contact with the ubiquity of the Roman Empire in its many guises, left their mark on his letters. The insistence that Paul was neither affected politically by the Roman Empire, nor interested in challenging or countering imperial claims consciously or otherwise, rests less on the rhetoric of his letters and more on a long tradition of interpretation which includes a particular approach to literary sources. Interpretive history has invented both a largely benevolent Roman regime through a tradition of Romanisation as well as a theologically truncated early Jesus community, wherein earthly politics were largely deemed absent. In many instances, conventionalist neglect of Pauline negativity towards Rome went hand in hand with the unwillingness to acknowledge Paul's Jewishness.

On the one hand, a theological reading of Paul does not have to be restrictive, naïve and pious, and other-worldly. On the other hand, however, conventionalist readings tend to foreclose on the socio-political dimension of the Pauline letters, generally if grudgingly granting the letters' socio-political relevance in a secondary or derived sense at best. Conventionalist scholars go off-course in a two-fold way: failing to see Pauline rhetoric's embeddedness in imperial discourse and ignoring the co-optation of Paul for a theological agenda established over a prolonged period of time. Paul's hostility toward the powers simultaneously had Jewish roots and was related to his opposition of Roman imperial power. The remaining challenge is how to perceive and understand the Pauline letters' understanding of the power of evil as it manifests in evil powers, making the distinction while at the same time keeping the connection between them alive.

\section{BIBLIOGRAPHY}

Ando, C 2000. Imperial Ideology and Provincial Loyalty in the Roman Empire. Classics and Contemporary Thought, vol. 6. Berkeley: University of California Press.

Arnold, CE 1992. S.v. Principalities and Powers. In The Anchor Yale Bible Dictionary, vol 5, ed. DN Freedman, 467. New York: Doubleday.

Barclay, JMG 2011 Pauline Churches and Diaspora Jews. WUNT. Tübingen: Mohr Siebeck.

Bauckham, R 1989. The Bible in Politics. How to Read the Bible Politically. Third Way Books, ed. T Dean. London: SPCK.

Bryan, C 2005. Render to Caesar. Jesus, the Early Church and the Roman Superpower. Oxford: Oxford University Press, 2005.

Carr, W 1981. Angels and Principalities. The Background, Meaning and Development of the Pauline Phrase hai archai kai hai exousiai. SNTSMS, vol. 42. Cambridge: Cambridge University Press.

Carter, W 2006. The Roman Empire and the New Testament: An Essential Guide. Abingdon Essential Guides. Nashville: Abingdon.

Carter, W 2011. Roman Imperial Power: A New Testament Perspective. In Rome and Religion: A Cross-Disciplinary Dialogue on the Imperial Cult, eds. J Brodd and JL Reed, 137-51. Writings from the Greco-Roman World Supplement series. Atlanta: SBL. 
Cobb, LS 2008. Dying to be Men - Gender and Language in Early Christian Martyr Texts. Gender, Theory, and Religion. New York: Columbia University Press.

Crossan, JD 2007. God \& Empire. Jesus against Rome, Then and Now. San Francisco: HarperSanFrancisco.

Donfried, KP 2011. "Paul's Jewish Matrix. The Scope and Nature of the Contributions." In Paul's Jewish Matrix, eds. TG Casey and J Taylor, 11-49. Studies in Judaism and Christianity. Rome: Gregorium and Biblical Press.

Fantin, Joseph D 2007. The Lord of the Entire World: Lord Jesus, a Challenge to Lord Caesar? New Testament Monographs, 31. Sheffield: Sheffield Phoenix Press, 2011.

Fredriksen P 2006. "Christians in the Roman Empire in the First Three Centuries CE." In $A$ Companion to the Roman Empire, ed. DS Potter, 587-606. Blackwell Companions to the Ancient World. Malden: Blackwells.

Freyne, S 1988. "Bandits in Galilee: A Contribution to the Study of Social Conditions in First-Century Palestine." In The Social World of Formative Christianity and Judaism. Essays in Tribute to Howard Clark Kee, eds. J Neusner, P Borgen, ES Frerichs and R Horsley, 50-68. Philadelphia: Fortress.

Galinsky, K 1996. Augustan Culture. An Interpretive Introduction. Princeton: Princeton University Press.

Garnsey, P \& R Saller 1987. The Roman Empire. Economy, Society and Culture. London: Duckworth.

Gradel, I 2002. Emperor Worship and Roman Religion. Oxford Classical Monographs. Oxford: Clarendon.

Grundmann, W 1985. S.v. dýnamai [to be able], dynatós [able], dynatéo [to be able], adýnatos [unable], adynatéō [to be unable], dýnamis [ability, power], dynástēs [ruler], dynamóó [to give power], endynamóō [to give power]. In Theological Dictionary of the New Testament, eds. G Kittel, G Friedrich and GW Bromiley, 186191. Grand Rapids: Eerdmans.

Harrill, JA 2011. "Paul and Empire: Studying Roman Identity after the Cultural Turn." Early Christianity 2(3):281-311.

Horsley, RA \& JS Hanson. 1985. Bandits, Prophets, and Messiahs: Popular Movements at the Time of Jesus. Minneapolis: Winston.

Horsley, RA 1997. "The Gospel of Imperial Salvation: Introduction.” In Paul and Empire. Religion and Power in Roman Imperial Society, ed. RA Horsley, 10-24. Harrisville: Trinity Press International.

Johnson-DeBaufre, M 2012. "Historical Perspectives. Which Past? Whose Past?" In Studying Paul's Letters. Contemporary Perspectives and Methods, ed. JA Marchal, 13-32. Minneapolis: Fortress.

Kim, S 2008. Christ and Caesar. The Gospel and the Roman Empire in the Writings of Paul and Luke. Grand Rapids: Eerdmans.

Kwok, P 2006. "Making the Connections: Postcolonial Studies and Feminist Biblical Interpretation.” In The Postcolonial Biblical Reader, ed. RS Sugirtharajah, 45-63. London: Blackwell.

Lopez, D 2011. "Visualizing Significant Otherness. Reimagining Paul(ine Studies) Through Hybrid Lenses." In The Colonized Apostle. Paul through Postcolonial Eyes, ed. CD Stanley, 74-94. Paul in Critical Contexts. Minneapolis: Fortress. 
Martin, DB 2005. Introduction. In The Cultural Turn in Late Ancient Studies. Gender, Asceticism, and Historiography, eds. DB Martin, and PC Miller, 1-21. Durham \& London: Duke University Press.

Mattingly, DJ 2010. Imperialism, Power, and Identity: Experiencing the Roman Empire. Princeton: Princeton University Press.

Milnor, K 2005. Gender, Domesticity, and the Age of Augustus. Inventing Private Life. Oxford Studies in Classical Literature and Gender Theory. Oxford: Oxford University Press.

Moore, SD 2006a. Empire and Apocalypse. Postcolonialism and the New Testament. The Bible in the Modern World, vol. 12. Sheffield: Sheffield Phoenix.

Moore, SD 2006b. Mark and Empire: "Zealot" and "Postcolonial" Readings. In The Postcolonial Biblical Reader, ed. RS Sugirtharajah, 193-205. London: Blackwell.

Oakes, P 2005. "Re-Mapping the Universe: Paul and the Emperor in 1 Thessalonians and Philippians." Journal for the Study of the New Testament 27:301-22.

Polaski, SH 1999. Paul and the Discourse of Power. Gender, Culture, Theory, vol. 8; Biblical Seminar, vol. 62. Sheffield: Sheffield Academic Press.

Polaski, SH 2005. A Feminist Introduction to Paul. St Louis: Chalice.

Porter, SE \& AW Pitts 2013. "Greco-Roman Culture in the History of New Testament Interpretation: An Introductory Essay." In Christian Origins and Greco-Roman Culture. Social and Literary Contexts for the New Testament, eds. SE Porter \& AW Pitts, 1-12. Texts and Editions for New Testament Study, vol 9; Early Christianity in Its Hellenistic Context, vol 1. Leiden: Brill.

Price, SRF 1984. Rituals and Power. The Roman Imperial Cult in Asia Minor. Cambridge: Cambridge University Press.

Punt, J 2012a. "Empire and New Testament Texts: Theorising the Imperial, in Subversion and Attraction." HTS Teologiese Studies/Theological Studies 68(1), Art. \#1182, 11 pages. http://dx.doi.org/10.4102/hts. v68i1.1182

Punt, J 2012b. "Violence in the New Testament, and the Roman Empire. Ambivalence, Othering, Agency." In Coping with Violence in the New Testament, eds. PGR de Villiers and JW van Henten, 23-39. STAR vol 16. Leiden: Brill.

Punt, J 2013. "The Interpretation of the New Testament as the Study of Texts and Contexts: Hermeneutics, Identities, Communities.” Acta Theologica 33(2):113-132.

Punt, J 2015. "Paul's Jewish Identity in the Roman World: Beyond the Conflict Model." In Paul the Jew: A Conversation between Pauline and Second Temple Scholars. Edited by CA Segovia \& G Boccaccini (forthcoming).

Reed, AY \& NB Dohrmann 2013. "Introduction: Rethinking Romanness, Provincialising Christendom." In Jews, Christians, and the Roman Empire. The Poetics of Power in Late Antiquity, eds. NB Dohrmann \& AY Reed, 1-22. Philadelphia: University of Pennsylvania Press.

Reid, DG 1993. "S.v. Principalities and Powers.” In Dictionary of Paul and his Letters, eds. GF Hawthorne, RP Martin and DG Reid, 746-752. Downers Grove: InterVarsity.

Rosen-Zvi, I \& A Ophir 2015. "Paul and the Invention of the Gentiles." The Jewish Quarterly Review 105(1):1-41.

Schüssler Fiorenza, E 2000. "Paul and the Politics of Interpretation. In Paul and Politics. Ekklesia, Israel, Imperium, Interpretation. Essays in honor of Krister Stendahl, ed. RA Horsley, 40-57.Harrisburg: TPI. 
Seesengood, RP 2005. "Hybridity and the Rhetoric of Endurance: Reading Paul's Athletic

Metaphors in a Context of Postcolonial Self-Construction." The Bible and Critical

Theory 1(3):1-16. DOI: 10:2104/bc050016.

Sharp, CJ 2013. "Mapping Jeremiah as/in a Feminist Landscape: Negotiating Ancient and Contemporary Terrains." In Prophecy and Power: Jeremiah in Feminist and Postcolonial Perspective, eds. CM Maier and CJ Sharp, 38-56. Library of Hebrew Bible/Old Testament Studies, vol. 577. London: Bloomsbury.

Stanley, CD 2011. "Paul the Ethnic Hybrid? Postcolonial Perspectives on Paul's Ethnic Categorizations." In The Colonized Apostle. Paul through Postcolonial Eyes, ed. CD Stanley, 110-26. Paul in Critical Contexts. Minneapolis: Fortress.

Versnel, HS 2011. Coping with the Gods. Wayward Readings in Greek Theology. Religions in the Graeco-Roman World, vol. 173. Leiden: Brill.

White, J 2009. “Anti-Imperial Subtexts in Paul: An Attempt at Building a Firmer Foundation." Biblica 90(3):305-33.

Wink, W 1984. Naming the Powers. The Language of Power in the New Testament. Philadelphia: Fortress.

Wink, W 1992. Engaging the Powers. Discernment and Resistance in a World of Domination. Minneapolis: Fortress.

Wright, NT 1994. "Gospel and Theology in Galatians." In Gospel in Paul: Studies on Corinthians, Galatians and Romans for Richard N. Longenecker, eds. LA Jervis \& P Richardson, 222-239. JSNT, Supplement Series 108. Sheffield: Sheffield Academic Press.

Wright, NT 2000. "Paul's Gospel and Caesar's Empire.” In Paul and Politics. Ekklesia, Israel, Imperium, Interpretation. Essays in Honor of Krister Stendahl, ed. RA Horsley, 160-83. Harrisville: TPI.

Zerbe, G 2012. Citizenship. Paul on Peace and Politics. Winnipeg: CMU. 